非がん性慢性疼痛に対するオピオイド使用一患者選択・評価・モニタリングをどのようにおこなうか？一

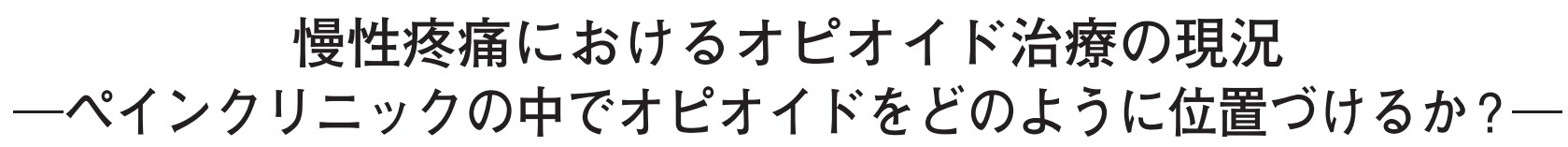

井関明生*

\begin{abstract}
[要旨］非がん性慢性疼痛は治癒が期待される期間を過ぎても持続する痛みの総称であり，その病 態は多彩で診断や治療が難しい疾患として知られている．近年，本邦でもこの非がん性慢性疼痛に 対してオピオイド治療が導入され, その有効性が認められつつあるが, 一方麻薬による依存, 嗜癖, 乱用等さまざまな問題点も指摘されている. 今回, われわれは疼痛治療を主に行っている医師を対 象としたアンケートを行い, オピオイド治療の現状と課題を探ってみた. その結果, オピオイド治 療は有用な治療法の一つではあるが, 現段階では限定的に用いるべきであること，また実践におい ては慎重な患者選択と定期的なモニタリングが重要であることが示唆された.

キーワード : 慢性疼痛, オピオイド, アンケート, モニタリング
\end{abstract}

はじめに

ペインクリニック診療において，慢性疼痛は頻繁 に遭遇する症状であるとともに，治療の難しい厄介 な症状でもある。薬物療法や神経ブロック, 理学療 法，心理療法などさまざまな手段を駆使してもなか なか満足してもらえる効果が得られず，患者に我慢 を強いることもしばしばである。それ故，この慢性 疼痛の克服は患者の悲願でありペインクリニシャン に課せられた命題でもある。

ところで，近年非がん性慢性疼痛に徐放性オピオ イドの使用が公式に認められるようになり，ペイン クリニック診療においても鎮痛手段としてょり積極 的にオピオイドを用いる機会が増えつつある。こう した傾向は治療に行き詰まった慢性疼痛患者には福 *徳島大学病院麻酔科
音となることであろう。しかし，非がん性慢性疼痛 にオピオイドを使用することについては，嗜㾕や依 存，乱用などの面から危険視する声もあり，まだま だ解決すべき課題が多く残っている。ここでは，ま ず非がん性慢性疼痛の病態や診療方法について再考 するとともに，本疾患に対するオピオイド治療の現 況や問題点, また今後の展望などについて, 疼痛治 療を実践されている医師を対象としたアンケート調 査の結果をもとに考えてみたい.

\section{I 慢性疼痛の現状}

\section{1. 定義と有病率}

慢性疼痛は1990年にBonicaが，「疾患が通常治 癒するのに必要な時期を越えているにもかかわら

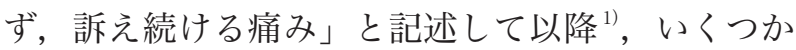




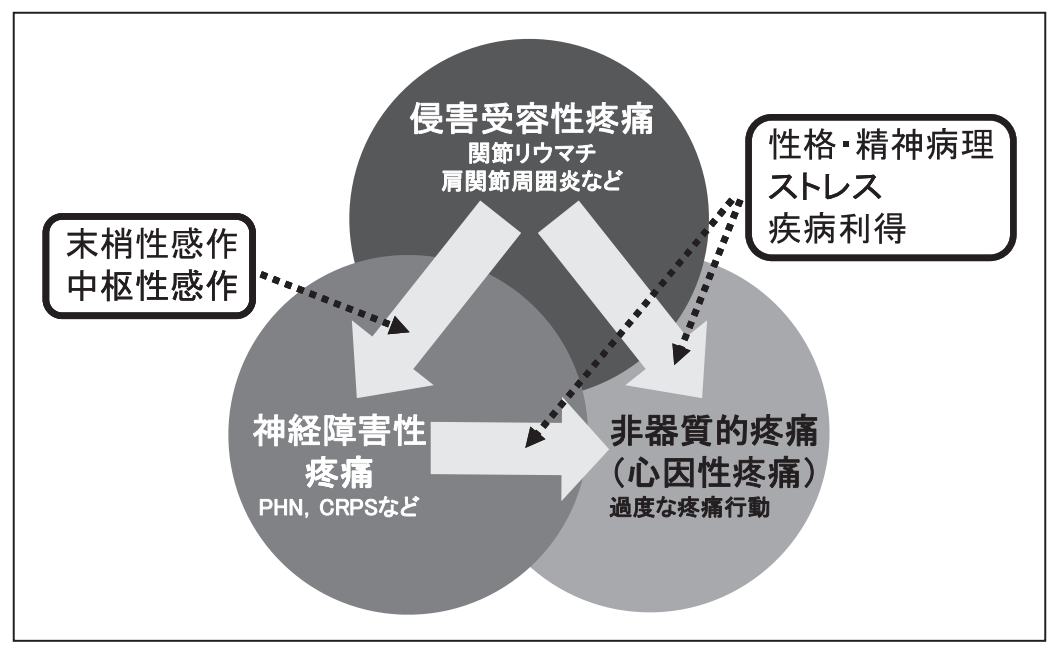

図1 慢性疼痛の病態

の改訂を受け，現在は 2003 年にInternational Association for the Study of Pain(IASP)がまとめた 定義が広く用いられている ${ }^{2)}$ 。それによると, 慢性 疼痛とは治癒に至ると期待される期間，すなわち 3 カ月以上持続する悪性疾患に由来しない痛みとされ ており，その有病率は欧州や豪州などでおよそ20 〜 50\%ともいわれている. また本邦でのいくつかの 調査においても20\%前後の有病率が報告されてお $\eta^{3)}, 5$ 人に 1 人以上でなんらかの長びく痛みに悩 んでいる実態がうかがえる。

\section{2. 病態}

慢性疼痛を構成する要素として, 侵害受容性疼痛, 神経障害性疼痛, 非器質的疼痛 (心因性疼痛)の 3 つ が考えられている(図1)。各要素単独でも長期化す ることで慢性疼痛としてとらえることになるが, 通 常はこれらが互いに関連した複合性の病像を呈して おり，比較的重篤な症例では特に神経障害性疼痛が 主因となっていることが多いように思われる。また 長期化した侵害受容性疼痛が引き起こす末梢神経感 作で病的な痛みが生じることはよく知られてお $り^{4)}$, 多くの症例でこのような不可逆的な可塑的変 化を通じて神経障害性疼痛への病態移行が進んでい くのかもしれない.

\section{3. 診断}

Loeserの痛みの多層モデルによると，痛みは $4 つ$ の階層に分かれており，最初に侵害受容を受け，そ れを知覚および認知し，その後陰性感情である苦悩 を経て, 痛从行動を引き起こすといわれている ${ }^{5}$. 通常，他者が観察できるのは最終段階の痛み行動だ けであり，これには疼痛の訴えや回避行動のほか, visual analogue scale(VAS) や痛み度，質問紙法な ど一般に痛みを診断するために用いられるッールの 評価結果も含まれる。ただ，いずれも途中の階層に 関係すると思われる患者の性格や知性, 身体・精神 状態などの影響を受けることから，どうしても曖昧 な結果が含まれることは否めない. したがって，正 しい評価を得るためには一つの側面だけを追うので はなく, 患者の全容を広く把握し系統立てた診断を 行う必要がある。

近年，神経障害性疼痛の診断ツールとして，Pain DETECT ${ }^{6}$ やLANSS (Leeds Assessment of Neuropathic Symptoms and Signs) ${ }^{7)}$ が開発され，本邦で も導入されつつある。いずれも神経障害性疼痛に特 有の症状や所見をわかりやすく問うものであり，結 果をスコア化することで客観的に神経障害性疼痛の 要素を判別できる。また，米国の Institute for Clinical Systems Improvement(ICSI)が作成した「成 
人の慢性疼痛に対する評価ガイドライン」は，患者 の痛みを身体・心理・社会的側面から多角的に観察 し包括的に評価した上で痛みの管理方法を立案する 手法を採用している，今後このようなツールやガイ ドラインを参考にすることで，本邦の実状に応じた 慢性疼痛の幅広い診断基準が作成されることを期待 したい.

\section{4. 治療}

慢性疼痛の治療として，これまで薬物療法を中心 に理学療法や心理療法，また特殊治療として神経ブ ロック(神経破壊を含む)や脊髄刺激療法，各種手術 療法までさまざまな方法が考案され実践されてき た。しかしながら，患者が満足するような改善をも たらす治療法が見つかることは少なく，多くはいく つかを組み合わせることでなんとか症状を和らげる といった現状があるように思われる。

そもそも慢性疼痛の定義や病態について考える と，重症度の差にかかわらず完治に至ることは少な いことから，まず医師や患者は通常の疾患とは異な る概念をもって治療に臨む必要がある。すなわち, 治癒を目指すのではなく緩和を求めるという考え方 が重要であり, 具体的には目標を疼痛の消失ではな く日常生活の向上や社会生活への復帰などに設定し て，それが達成されるような治療を実践していくべ きである。先に記したICSIのガイドラインでは， 痛み以外にも身体活動やストレス状態の改善などを 治療目標として設定し，さまざまな鎮痛処置だけで なく理学療法や心理療法を積極的に取り入れなが ら，最終的には疼痛の自己管理をゴールとするプロ グラムを提唱している．ただ，そのためには治療に 先立って患者に正しい病態の認知（ある程度痛みは 残り続けるという事実があること)や治療に対する 理解(疾患を治すのではなく症状を和らげる処置で あること)を確立させておく必要があり，こういつ た認知行動療法がうまく導入できるかどうかは予後 にある程度影響を及ぼすようにも思われる。

\section{II＼cjkstart慢性疼痛におけるオピオイド治療}

\section{1. オピオイド治療の適応と困難さ}

本邦における医療用オピオイドの使用量は近年 徐々に増加しているとはいえ，主要各国と比較する とその消費割合は格段に小さい ${ }^{8)}$. 特に非がん性疼 痛に対する使用頻度は少ないことから，すでに慢性 疼痛にオピオイド治療が日常的に行われている欧米 諸国とは異なり，依存や乱用，中毒といったことが 大きな問題になることはこれまであまりなかった。 しかし，もしオピオイド治療が本邦でも本格的に導 入されることになれば，決してこういった問題を避 けることはできないであろう。またこのことは単に 一個人の疼痛治療という枠を超えて，社会全体に影 響する問題としてとらえる必要もある。そういった 意味で，患者の選別やモニタリング，処方に関する 運用などは厳格に行われなければならない.

がん性疼痛では，疼痛の原因や性状などの診断が 比較的容易であり，また疼痛は進行性であること， さらにそれに伴って必然的に日常活動の低下が生じ ることなどから，患者が訴える疼痛の大きさに応じ たオピオイド量が投与される。しかし非がん性疼痛 においては，逆に診断の難しい非進行性の良性疾患 であることが多いことや，治療の目標を患者の日常 活動の改善や自立に設定することから，がん性疼痛 で用いられているようなオピオイドの処方は行うべ きでない9 。こういった違いからも，非がん性疼痛 におけるオピオイド治療の難しさを感じさせられる。

\section{2. オピオイド治療の原則}

残念ながら，本邦では十分コンセンサスの得られ た非がん性疼痛に対するオピオイド治療のガイドラ インはまだない，米国疼痛学会が示したガイドライ ンではオピオイド治療は有効な方法としながらも, 副作用や依存・乱用を避けるためにオピオイドの使 用法やリスク評価と管理の双方に対する臨床スキル と知識を医療者に求めている ${ }^{10)}$. 具体的には注意深 い患者選択に始まり，包括的な治療計画の策定，患 


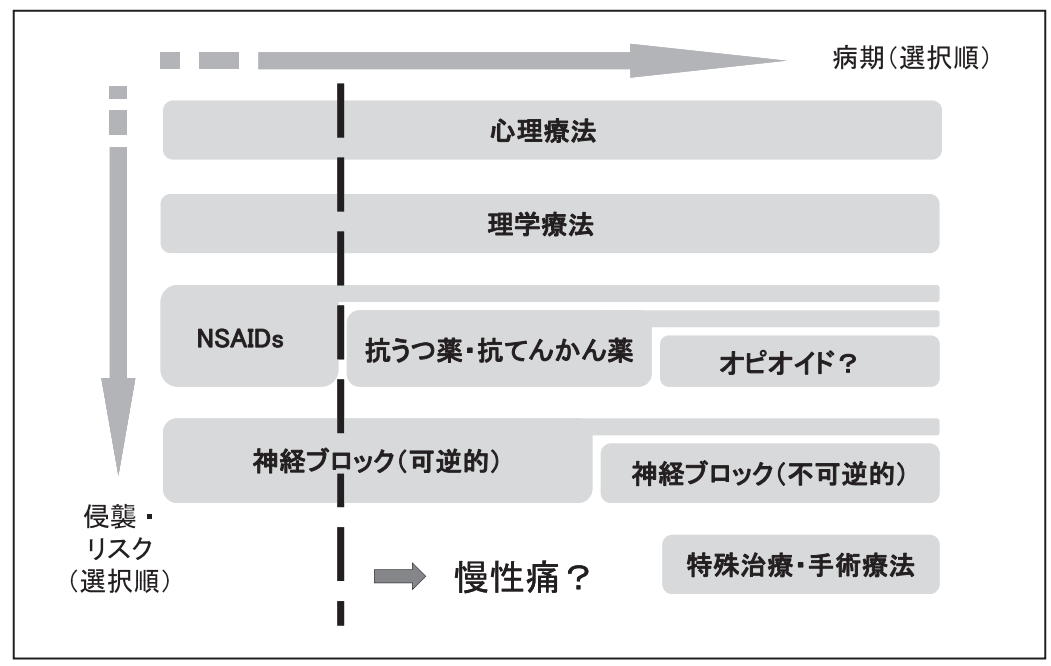

図2 疼痛治療手段の選択順

者への十分な説明と合意, 薬物の慎重な投与と管理, そして定期的な評価を行いながら，治療の妥当性を 検証する。このように，先述の身体的，精神的なり スク以外に，医療者・患者双方とも非常に手間や時 間のかかる治療であることから，安易な気持ちでオ ピオイド治療を開始することは慎むべきである.

\section{3. オピオイド治療の位置づけ}

さて，慢性疼痛に対する鎮痛手段としては先ほど 述べたようにさまざまなものが実践されてきたが, オピオイド治療ははたしてその中でどのような位置 づけでとらえるべきであろうか？ ペインクリニッ クに限らず治療は原則として安全性が高いものや侵 襲度の低いものから優先的に行われる。そういった 観点から図 2 に示すような一般的な疼痛治療選択の モデルを考えてみた。その中でオピオイド治療は, あるレベルを超えるような高い侵襲や危険性を伴う 治療を選択する際に，代替となる治療として検討さ れるのではないかと予想される。この考えを検証す るべく, 今回疼痛治療を専門的に行っている施設か らアンケートを通じて意見を集め分析を試みた。

\section{III アンケート結果からみるオピオイド使用状況}

ウェブで公開されている疼痛治療専門施設をラン ダムに抽出し, オピオイド治療の実態に関するアン
ケートを行った。アンケートは無記名回答で, 回答 期間は平成 $22(2010)$ 年 8 月 27 日から 9 月 10 日まで, また回収方法はファックスによる返信で行い, 総計 394 の施設より 139 の有効回答(回答率35.3\%)を得た。

\section{1. 対象施設の背景}

対象は疼痛治療を専門的に行っている施設とした ことから，回答もやはり大病院から多く得られ，ま た標榜科は麻酔科・ペインクリニックが $90 \%$ 以上を 占めた。回答者の年齢は 40 歳代と 50 歳代が中心で あった。なお，回答いただいた施設の所在地域につ いてはほぼ偏りなく分布していた。

2. オピオイドの使用状況 $(n=139$, 図3)

今回のアンケート結果から，75\%の施設で非がん 性慢性疼痛に対してオピオイドを現在使用してお り, 将来的にオピオイド治療を行う予定である意見 も合わせると $90 \%$ 近くにのぼつた。これは同年初め に行われた全医師対象のアンケート結果 $(44 \%)^{11)}$ と 比較するとかなり高い值であり，またやはり同年に ヤンセンファーマ社が専門科別に調ベたアンケート 結果 ${ }^{12)}$ (内科医や整形外科医で $10 \sim 25 \%$ あるるのに 対して麻酔・ペインクリニック医では約 $60 \%$ がオピ オイドを使用) と同様の結果を示した。このことか ら疼痛治療を専門に行っている医療施設では非がん 性慢性疼痛に対するオピオイド治療への高い関心と 


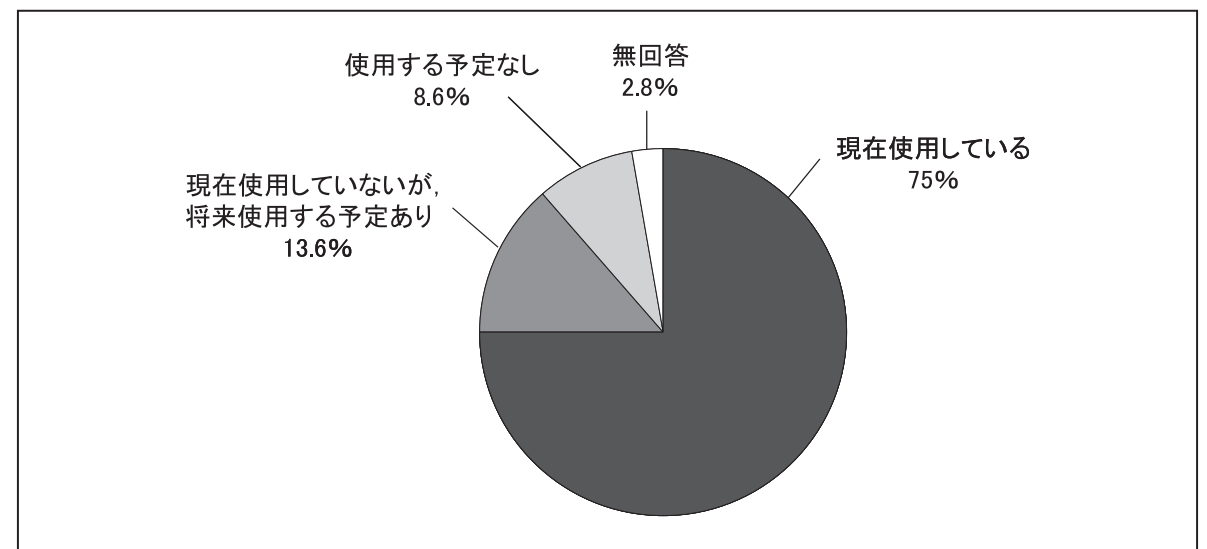

図3 非がん性慢性疼痛患者に対してオピオイドを使うか? [回答結果] ( $n=139)$

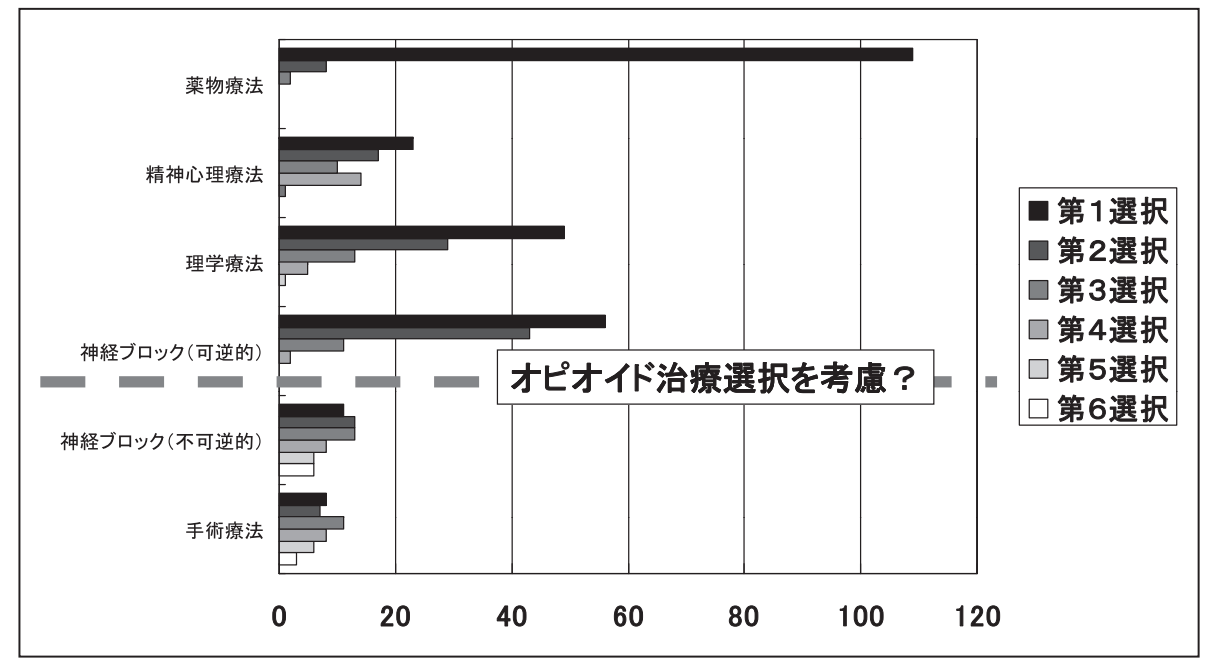

図4 オピオイド投与の前に行っておくべき治療は？[回答結果] (複数回答 $\mathrm{n}=124)$

理解，また積極性がうかがえる。

3. オピオイド治療導入のタイミング $(n=124$, 図 4)

オピオイド治療の前に行っておくべき治療とし て，オピオイド以外の薬物療法や精神心理療法，理 学療法，可逆的な神経ブロックをあげた意見が多数 得られた。一方, 不可逆的な神経ブロックや手術療 法といつた侵襲度の高い治療は, 比較的慎重に選択 される傾向が認められる。これと同様の結果が先の アンケート調査 ${ }^{12)}$ でも得られており，どうやらオピ オイド療法は保存的治療のほぼ最終段階に用いられ るものといつた認識が一般的であるように思われる。
4. オピオイドの種類と至適使用量と上限量, レスキュ 一の設定 (図 5, 図6)

主として使用されるオピオイドとしてコデインを 用いる施設がやや多かったが，モルヒネやフェンタ ニルもほぼ同レベルで用いられている。至適使用量 については，モルヒネで $10 〜 50 \mathrm{mg} /$ 日が最も多く, 次いで $50 \sim 100 \mathrm{mg} /$ 日，またフェンタニルでは $2.1 \mathrm{mg} / 3$ 日， $4.2 \mathrm{mg} / 3$ 日の順で多く，ともに両方で 70\%以上を占めた。コデインは比較的投与量の範囲 が広く，30〜160mg/日で多く用いられていた。

オピオイドの上限量として，現在モルヒネ換算で 


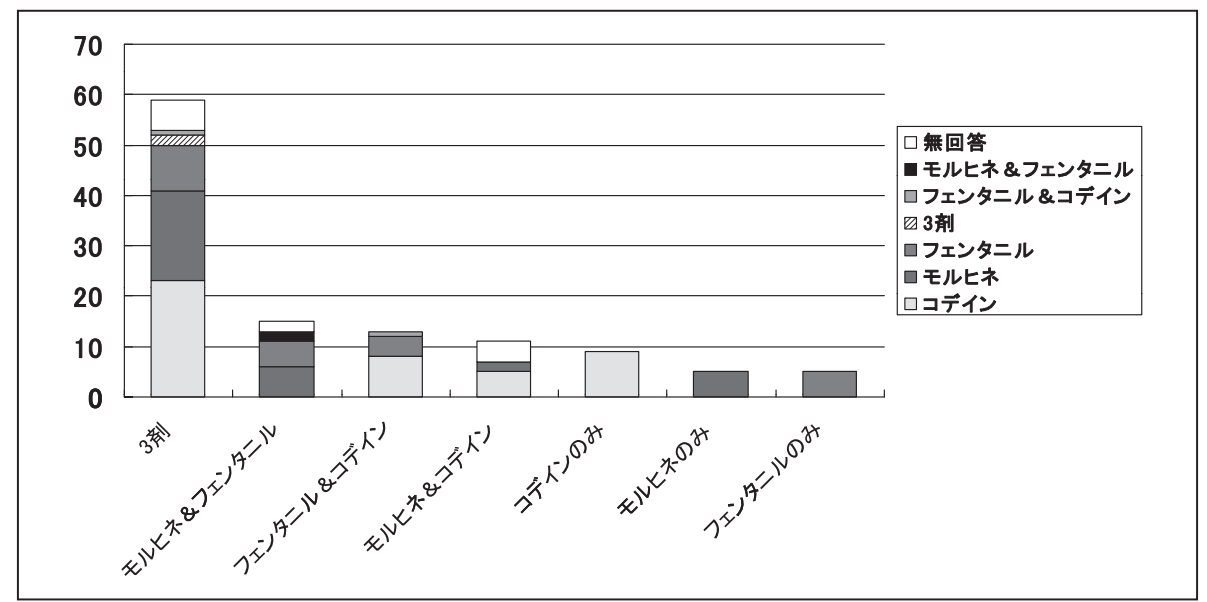

図 5 主として用いるオピオイドの種類は? [回答結果] (複数回答 $\mathrm{n}=117$ )

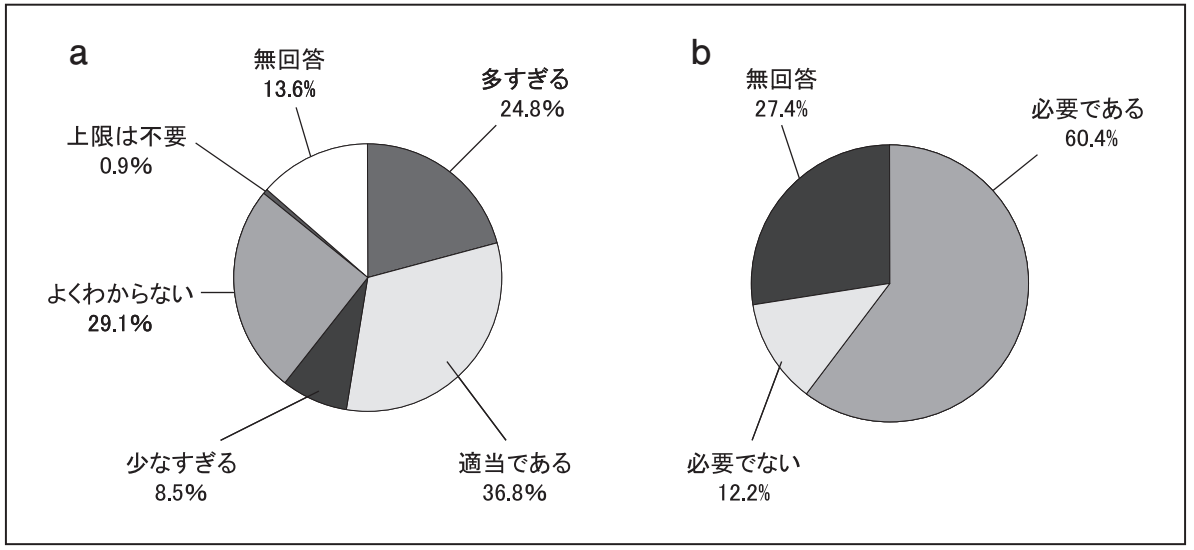

図6 a : モルヒネ換算量で, 200mg/day は多いか? 少ないか? [回答結果] (n=134)

b : オピオイド治療において, レスキューは必要か? [回答結果] $(n=134)$

一般的には $200 \mathrm{mg} /$ 日が提唱されている。これにつ いては「適当」もしくは「多すぎる」とした意見が 半数以上を占めたが，わからないとする意見も $30 \%$ 程度あり, 非がん性慢性疼痛に対するオピオイドの 至適投与量設定の難しさが表われている.

突出痛に対する短時間作用性オピオイド(レスキ ュー)の使用については, 今回必要とする意見が 60\%程度にのぼった。この結果からはなんとか患者 の痛みを軽減しょうという現場医師の配慮がうかが える反面, 依存や乱用のリスクが高まる可能性を危 惧する意見 ${ }^{91}$ 10) も反映されているようにも感じら れ，レスキュー実施の可否については今後さらなる
検討が必要と思われる。

\section{5. 先行オピオイドの忍容性確認期間, 治療中の外来通 院間隔 (図 7, 図8)}

現在, フェンタニルパッチを導入する前にモルヒ ネなどの先行オピオイドの効果や副作用を確認しな ければならないが，その忍容性確認の期間について は特に規定されていない. 今回の調査でも各施設に よってさまざまであり, 最も短いもので 3 日以内, また慎重な施設では 1 カ月以上を設けるなど，特に 偏った傾向は認められなかった。したがって,この 結果からは至適忍容性確認期間を論じることはでき ないが，これは患者選別をする上でも必要な過程で 


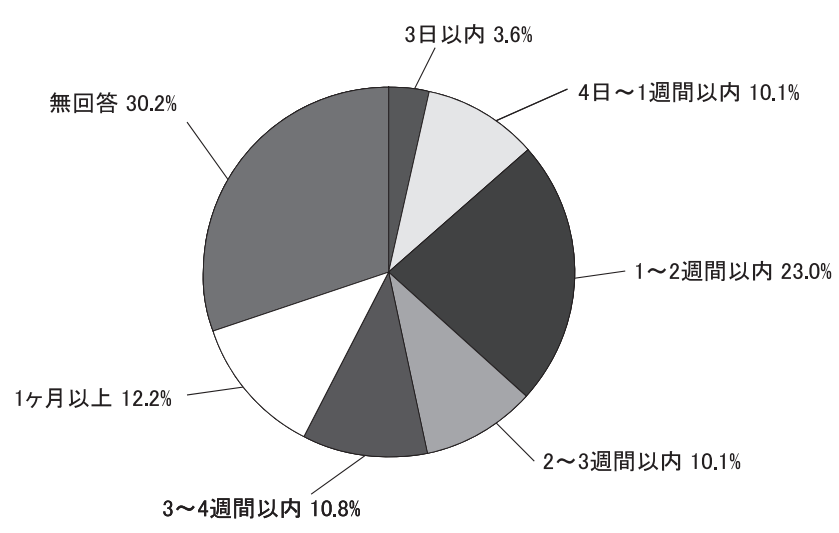

図7 先行モルヒネの忍容性を確認するための至適期間は? [回答結果] ( $\mathrm{n}=134)$

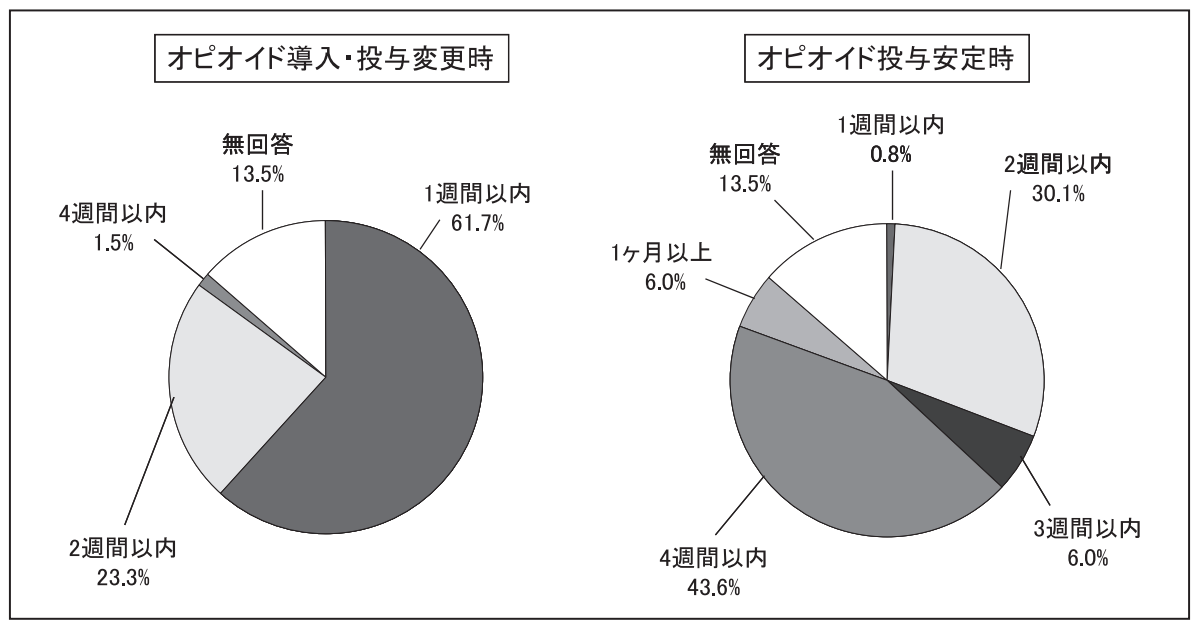

図 8 オピオイド治療を安全に行うための至適外来通院期間は? [回答結果] $(n=133)$

あるため，やはりある程度余裕をもって行うべきと 思われる。また，フェンタニル製剤の効果確認にモ ルヒネ製剤を使用することについての疑義もあり， 今後は確認期間だけでなく方法や評価についてもそ の妥当性を議論する必要があるのかもしれない.

オピオイド治療中の外来通院間隔については，オ ピオイド導入時や投与量変更時は 1 週間以内, 安定 時は2〜4週程度とする意見が多く，通院患者の安 全性と利便性を考慮した結果と受け止められる。
6. 効果の判定, 薬物の確認状況, 飲酒・車の運転, 処 方医師の固定 (図 9)

オピオイド治療の効果判定の評価項目として，や はりVASやnumerical rating scale(NRS)のような 直接的な疼痛評価だけでなく，日常活動の変化をあ げた意見が多かった。ほかにも，患者の表情や笑顔 の有無, 副作用の程度など, さまざまな患者の状態 を総合的に観察して決めるといった独自の意見もあ った。このことから，多くの疼痛治療専門医師が患 者の日常活動の改善を目標に治療を行っている状況 がうかがえる. 


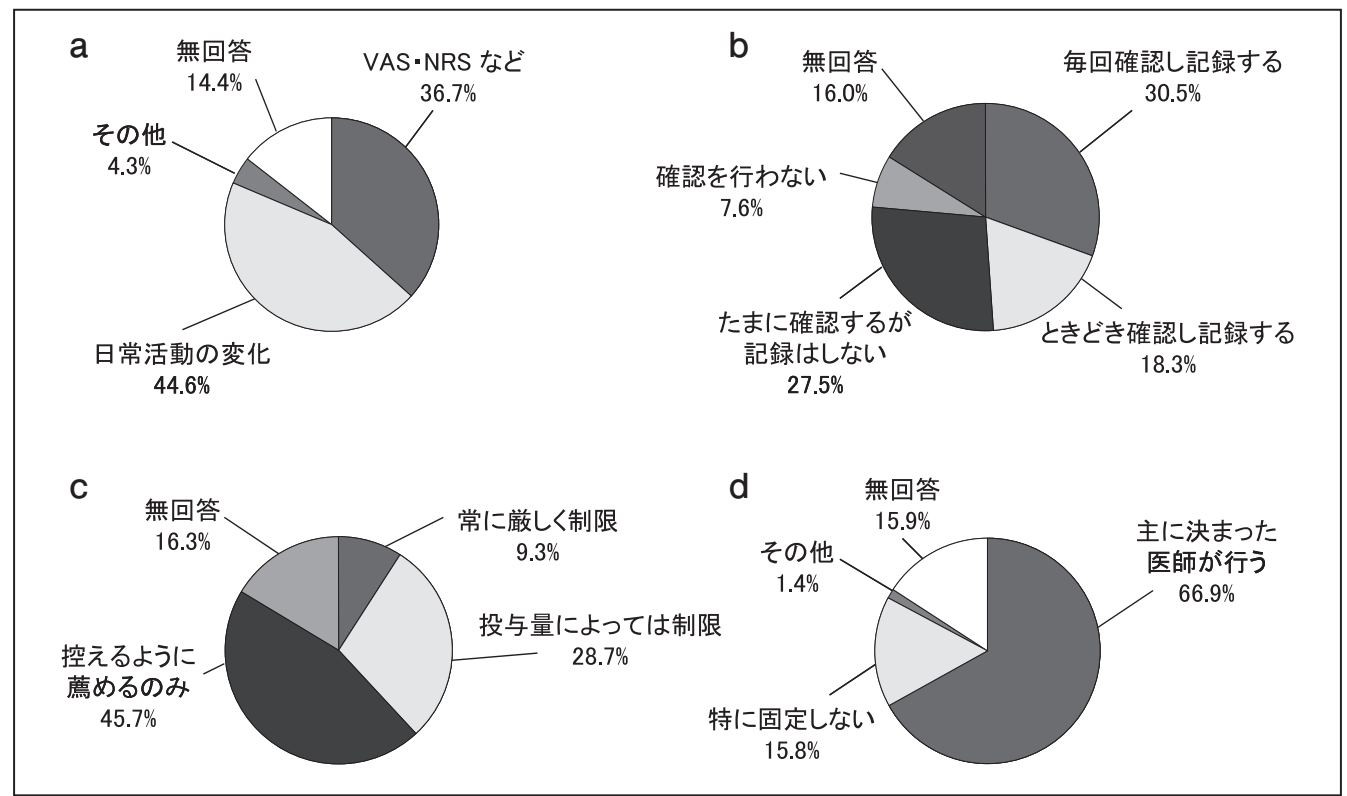

図 $9 \mathrm{a}$ ：オピオイドの増減を行う際に有用なパラメータは? [回答結果] $(n=133)$

b : 外来にてオピオイド投与を行う場合, 診察時に服用量や残量の確認は?

[回答結果] $(n=131)$

c：外来にてオピオイド投与を行う場合, 飲酒・車の運転の制限は? [回答結果] ( $n=129)$

$\mathrm{d}$ : オピオイドの処方は常に決まった医師が行っているか? [回答結果] ( $n=129)$

一方，処方したオピオイドの使用状況について確 認および記録している施設は $50 \%$ 以下であった。こ れは処方に関する事務的な煩雑さや診察時間の延長 といつた問題が関係しているのかもしれないが，才 ピオイドは乱用などが懸念される薬物だけに多忙な 外来診療においてもできる限り厳密な管理が望ま れる。

飲酒や車の運転の制限については何もオピオイド に限ったことではないが，やはり重篤な副作用もあ ることから十分注意する必要はある。とはいえ，自 動車の運転は地方都市などでは通院をはじめ生活に 不可欠であり思い切った制限は行いにくい. また飲 酒に関しても，その摂取量にもよるが，完全に禁酒 を強制するまでの指導も行いにくい.こういつた現 場での悩みが今回のアンケート結果でも表われてお り，一部制限や推奨までにとどめる意見が多く認め られた。

オピオイドを処方する医師については，66\%程度
の施設で固定されていた。これは医師と患者の信頼 関係がより重要であるという，オピオイド治療の特 殊性が反映された結果と思われる。しかし，医師の 異動や患者の転居などが生じた場合，誰が引き継い で処方を行うのか? といったことでトラブルも発 生しうる。こういった問題を回避するためには，や はりチーム医療や地域連携の必要性についての検討 も行うべきであろう.

\section{7. オピオイド治療に対する障害 (図 10)}

以上のアンケート内容を総合的に踏まえ, 今後の オピオイド治療を実践していく上で障害となる問題 点を最後に質問した。

その結果，対象患者の選別 (23\%)，薬物の管理 (19\%)，依存・中毒の発生(15\%)などをあげる意見 が多かった(複数回答)。その他, オピオイドの減量・ 中止の困難さ $(10 \%)$, 処方手続きの煩雑さ $(7 \%)$, また治療効果の判定の曖昧さや神経障害性疼痛への 適応の是非など(各6\%)を問題にする意見もあった。 


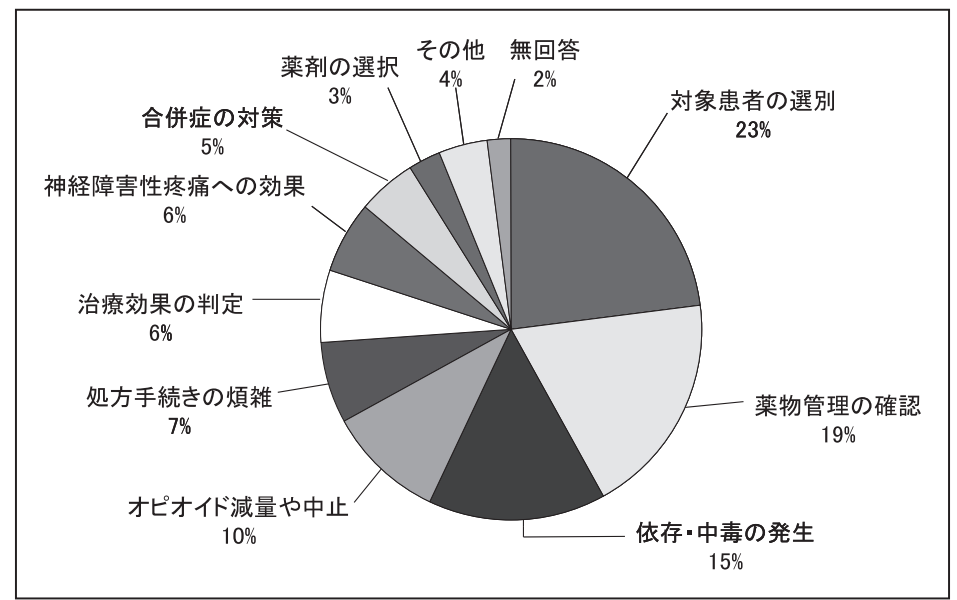

図10 非がん性慢性疼痛に対するオピオイド治療の障害となる 問題点は? [回答結果] (複数回答 $\mathrm{n}=139$ )

この結果はオピオイド治療の実践に際して, 医師に 高い知識や技術，経験が求められるだけでなく，さ まざまなリスクや身体的・心理的負担をもたらして いることを意味している，今後，本邦でのオピオイ ド治療の普及・発展のためにはこのような障害を取 り除いていく必要があり，それには本治療に精通し た専門医の養成や認定，診療に伴う負担への正当な 評価，また地域社会での理解を得るための啓発活動, さらにはエビデンスの蓄積と分析などが有効ではな いかと考える。

\section{まとめ}

非がん性疼痛に対するオピオイド治療は，有効な 治療手段となりうるが現段階ではまだ限定的に用い るべきである。また位置づけとしては，大きな侵襲 や不可逆的な治療を行う場合に一緒に検討してもよ い治療なのかもしれない。ただし実践に際しては, 従来の治療概念を変え, 常に依存・乱用などのリス クやモニタリングに伴うさまざまな負担を覚悟して おかなければならない.

\section{参考文献}

1) Bonica JJ : Definitions and taxonomy of pain, The Management of Pain, 2nd ed. Edited by Bonica JJ. Lea
\& Febiger, Philadelphia, 1990, 18-27

2) International Association for the Study of Pain : Classification of chronic pain : descriptions of chronic pain syndromes and definitions of pain terms. Pain (Suppl 3) : S1-S226, 1986

3）厚生労働省：平成 19年国民生活基礎調查. 厚生労働省 ホームページ, 2007

4) Ferrari LF, Bogen O, Levine JD : Nociceptor subpopulations involved in hyperalgesic priming. Neuroscience $165: 896-901,2010$

5) Loeser JD, Egan KJ : Managing the Chronic Pain Patient. Edited by Loeser JD, Egan KJ. Raven press, New York, 1989, 6

6) Freynhagen R, Baron R, Gockel U, et al. : painDETECT : a new screening questionnaire to identify neuropathic components in patients with back pain. Curr Med Res Opin 22:1911-1920, 2006

7) Bennett M : The LANSS Pain Scale : the Leeds assessment of neuropathic symptoms and signs. Pain $92: 147-157,2001$

8）齊藤洋司，小川節郎，眞下節ほか：慢性疼痛に対する 薬物治療を中心とした治療実態調査一日本, 米国, ド イッの比較—. Pharma Medica $28: 137-147,2010$

9）廣瀬宗孝, 田畑麻里, 坂井美賀子ほか：慢性非がん性 疼痛患者に扔ける嗜癖を予防するための長期オピオイ ド療法.ペインクリニック $31: 221-224,2010$

10) Chou R, Fanciullo GJ, Fine PG, et al. : Opioid treatment guidelines: Clinical guidelines for the use of chronic opioid therapy in chronic noncancer pain. J Pain $10: 113-130,2009$

11）株式会社メディカル・オブリージュ：Med Peerポステ イング調査：非がん性疼痛に対する麻薬の使用に関し 
て.ヤンセンファーマ株式会社社内報, 2010

12）ニールセン・カンパニー株式会社：慢性疼痛に関する

調査. ヤンセンファーマ株式会社社内報, 2010

\title{
When Can Chronic Opioid Therapy Be Used for Chronic Non-Cancer Pain?
}

\begin{abstract}
Akio ISEKI
Department of Anesthesiology, Tokushima University Hospital

Diagnosis and therapy for chronic non-cancer pain that persists beyond the normal tissue healing time is very difficult, because it has many types of morbidity. Chronic opioid therapy has been effectively used in Japan for relieving this type of pain. However, chronic use of narcotic analgesics exposes the patient to the risk of narcotic dependence, addiction or abuse. We investigated the factors associated with chronic opioid therapy in Japan using questionnaires completed by doctors that treat patients suffering from chronic pain. The results suggested that chronic opioid therapy is an effective method for treating patients with chronic pain. However, this mode of therapy must be limited in patients with chronic non-cancer pain, and careful patient selection, as well as periodic monitoring of their pain and behavior is required.
\end{abstract}

Key Words : Chronic pain, Opioid, Questionnaire, Monitoring

The Journal of Japan Society for Clinical Anesthesia Vol.31 No.4, 2011 